\title{
Quality evaluation of mandarin and strawberry mixed fruit juice for total period of 90 days at room temperature
}

\author{
Sumayya Rani ${ }^{*}$, Alam Zeb ${ }^{2}$, Muhammad Ayub ${ }^{2}$ and Uzma Shahni ${ }^{3}$ \\ 1. Deparment of Agriculture (Food Science \& Technology), University of Swabi, Anbar Swabi-Pakistan \\ 2. Department of Food Science \& Technology, The University of Agriculture Peshawar-Pakistan \\ 3. Department of Health and Physical Education, Abdul Wali Khan University Mardan-Pakistan \\ *Corresponding author's email: Sumayya@uoswabi.edu.pk
}

Citation

Sumayya Rani, Alam Zeb, Muhammad Ayub and UzmaShahni. Quality evaluation of mandarin and strawberry mixed fruit juice for total period of 90 days at room temperature. Pure and Applied Biology. Vol. 7, Issue 1, pp174183. http://dx.doi.org/10.19045/bspab.2018.70021

Received: 25/10/2017 Revised: 29/12/2017

Accepted: $31 / 12 / 2017$

Online First: 20/01/2018

\section{Abstract}

The present study was designed to find the best mixing ratio of mandarin and strawberry juice, and to study the individual and combined effect of sodium benzoate and potassium sorbate on physiochemical and organoleptic characteristics of the product during storage. The juices from both fruits were mixed in different ratios $(1: 1,1: 2,1: 3,2: 1,3: 1)$ and were analyzed organoleptically. The product having both fruit juices in $(1: 1)$ was taken for further study. Total six samples $\left(\mathrm{S}_{1}, \mathrm{~S}_{2}, \mathrm{~S}_{3}, \mathrm{~S}_{4}, \mathrm{~S}_{5}\right.$ and $\left.\mathrm{S}_{6}\right)$ were preserved with different concentrations of sodium benzoate and potassium sorbate and were analyzed for their physiochemical $(\mathrm{pH}$, total soluble solids, $\%$ acidity, ascorbic acid, reducing and non-reducing sugar) and organoleptic characteristics (color, flavor, taste and overall acceptability) for 90 days at 15 days interval at room temperature. The average value for $\mathrm{pH}$, ascorbic acid and non-reducing sugars were decreased at $\alpha$ value $(<$ $0.05)$ while the average value for total soluble solids, percent acidity and reducing sugars were increased at $\alpha$ value $(<0.05)$. The average judges score for color, flavor, taste and overall acceptability of all samples was decreased at $\alpha$ value $(<0.05)$. $\mathrm{S}_{4}[(1: 1)+0.075 \%$ Sodium benzoate +0.025 Potassium sorbate] stayed more acceptable while $S_{6}$ [controlled] showed unsatisfactory results both physiochemically and organoleptically.

Keywords: Fruit juice; Mandarin; Preservatives; Quality evaluation; Strawberry; Temperature

\section{Introduction}

From past, man has been using fruits and vegetables as source of vitamins and minerals. These are utilized in fresh form as well as in the form of various products such as jelly, squash, jam and vegetable based beverages. [1].The blending and mixing terms refers to addition and mixing of ingredients to form a homogenous product rich with many essential nutrients [2].The work of [3] has explained the methods of mixing different products. For the first time the methodology for quality analysis of mixed fruit products such as juices, squashes developed by [4]. The mixing of different juices leads to high quality product to consumer [5]. In order to get best thirst quenching beverages [6], coconut water was added to lemon juice, which was not only able to satisfy consumer demands but was 
found rich in terms of nutritional significance. In a health conscious society the demands for low caloric, high fiber rich in vitamins and minerals beverages is increasing day by day. The simple solution for this is to blend different juices to get enriched product. [7].

Mandarin (Citrus reticulate) is among the most famous citrus fruits which has shiny color, attractive taste and aroma. In Pakistan, nearly $60 \%$ of gross citrus production consists of mandarin which is locally known as "Kinnow". Mandarin juice is very beneficial because it contains good amount of minerals and ascorbic acid [8]. It is a rich source of vitamin C (130\%), retinol(3\%), carotenes, pectin, citric acid and some minerals such as iron(4\%), phosphorus (3\%) and calcium (4\%). Ascorbic acid (vitamin C) plays a significant role in protecting health in various ways by absorbing iron from plant foods and formation and retention of collagen which keeps the body together by repairing and supporting bones, muscles and skin [9]. Generally this fruit is consumed in fresh as well as in processed forms such as ready to serve, juices based soft drinks, jelly, jam as well as marmalade. It is widely grown in Pakistan in many districts such as Lahore, Multan, Sargodha, Mianwali, Gujranwala, Jhang, Sahiwal etc while in KPK it is mainly grown in Peshawar, Swabi, Mardan, Swat, Hazara and Nowshehra. In Pakistan the total area under cultivation of citrus was 199.4 thousand hectares and its gross production was 2294.5 thousand tonnes during the year 2007-08[10].

Strawberry (Fragaria ananassa) belongs to kingdom plantae and family rosaceae. It is cultivated in several parts of world but is widely grown in Japan, USA, Lebanon, Itlay and Maxico [11]. In Pakistan it is cultivated in particular areas of Punjab (Narowal, Lahore and Islamabad), KPK (Mardan, Swat, Charsadda) and Balochistan (Ziarat). Strawberry is a freshly introduced crop in
Pakistan so its production is very low [12]. It is a tiny and fleshy red colored sweet fruit. Anthocyanin is responsible for its red color. Approximately $50 \%$ of sugars content consist of glucose. Strawberry is a good source of ascorbic acid (vitamin C) and flavonoids. Ascorbic acid is important for normal healthy skin, bones formation in infants and children [13]. The average sized strawberry fruit contains water $(91.75 \mathrm{~g})$, carbohydrates $(7.02 \mathrm{~g})$, fat $(0.37 \mathrm{~g})$, protein $(0.6 \mathrm{~g})$, vitamin c $(60 \mathrm{mg})$, fiber $(2.3 \mathrm{~g})$, potassium $(0.2 \mathrm{~g})$, calcium (21mg), magnesium (15mg), iron $(0.5 \mathrm{mg})$ and zinc $(0.15 \mathrm{mg})$. The outstanding flavor is due to some organic acids such as citric and maleic acid.

Titratable acidity range is $0.58-1.35 \mathrm{~g} / 100 \mathrm{~g}$ and $\mathrm{pH}$ is 3.27-3.86 that helps in stabilization of color. The range of total soluble solids is 8.0-11.5\% which are ideal for concentrates of juice desired in market. Strawberry is generally utilized in fresh as well as in processed forms [14].The fruit sugar is an instant source of energy that improves its taste and attracts children to consume the product happily. It provides fluids which prevents body from dehydration in hot weather, allergic reactions and in case of diseases. Fruits and vegetables can be $100 \%$ replaced by their juices [15].

Research work all around the world is exploring the importance of phytochemicals to the world. Strawberry is rich in anthocyanins and flavonoids which have strong capability to fight against cancer and mandarin is rich in vitamin $\mathrm{C}$ and citric acid which are strong antioxidants [16]. Mandarin is produced abundantly In Pakistan. Lack of proper storage facility causes loss of this fruit. About $30-50 \%$ of fruits and vegetables losses occur in developing countries including Pakistan [17 ]. Citrus fruits ranked first amongst them. The strawberry is very delicious but is very perishable fruit.

According to the survey, about 10 million liters of fruit juices are consumed per year in 
Pakistan. Citrus fruit and strawberry juices make a larger portion of beverages and food industry [18]. Keeping in view the nutritional significance, market demands and recommendations of health professionals the present study was designed. It will help to produce the fruit juice to overcome market demands and help the population to enjoy them throughout the year. It can help the dietitian to plan the diet for patients suffering from cancer, skin and bones diseases.

\section{Materials and methods}

Fresh and good quality mandarin and strawberries were purchased from local market of Peshawar and brought to the Food Processing Laboratories of Pakistan Council of Scientific and Industrial Research (PCSIR), Peshawar where research work was carried out. Mandarin and strawberries were washed with tape water. Mandarins were peeled and cut into halves with the help of pre sterilized stainless steel knife. Juice was then extracted by using Rose Head machine and filtered with the help of muslin cloth. Leaves were detached manually from strawberries. Juice was extracted with the help of mechanical pulper, filtered through muslin cloth and were mixed in different ratios as shown in Table 1.

Table 1. Mixing ratios of mandarin and strawberry juice

\begin{tabular}{|l|l|l|l|l|l|}
\hline & $\mathbf{R}_{\mathbf{1}}$ & $\mathbf{R}_{\mathbf{2}}$ & $\mathbf{R}_{\mathbf{3}}$ & $\mathbf{R}_{4}$ & $\mathbf{R}_{5}$ \\
\hline Mandarin & 1 & 1 & 1 & 2 & 3 \\
\hline Strawberry & 1 & 2 & 3 & 1 & 1 \\
\hline
\end{tabular}

All The mixing ratios were presented to a panel of judges selected from members of PCSIR. Using Grading points of Larmond one ratio, $\mathrm{R}_{1}$ (1:1) got maximum score. Further six treatments were made from the selected ratio of mixed fruit juice:

$\mathrm{S}_{1}=(1: 1)+0.1 \%$ Sodium Benzoate

$\mathrm{S}_{2}=(1: 1)+$ Potassium Sorbate

$\mathrm{S}_{3}=(1: 1)+0.05 \%$ Sodium Benzoate + $0.05 \%$ Potassium Sorbate
$\mathrm{S}_{4}=(1: 1)+0.075 \%$ Sodium Benzoate Sodium Benzoate $+0.025 \%$ Potassium Sorbate

$\mathrm{S}_{5}=(1: 1)+0.025 \%$ Sodium Benzoate + $0.075 \%$ Potassium Sorbate

$\mathrm{S}_{6}=$ control

All the samples were kept in $250 \mathrm{ml}$ bottles and were stored at room temperature for total periods of 90 days. They were analyzed both physiochemically and organoleptically at fifteen days interval.

\section{Physiochemical analysis}

All the samples were analyzed at room temperature physiochemically for $\mathrm{pH}$, total soluble solids (TSS), \% acidity, ascorbic acid, reducing and non-reducing sugar using standard method as explained by [19].

\section{Organoleptic evaluation}

All the samples were analyzed by a group of ten judges for color, flavor, taste and overall acceptability and score was given to them using 9-points hedonic scale according to the method described by [20].

\section{Statistical analysis}

All the results were computed using statistics two-way ANOVA as recommended by [21]. Means were separated using LSD test as described by [22].

\section{Results and discussion \\ pH of Mandarin and strawberry mixed fruit juice samples}

The average value of $\mathrm{pH}$ was decreased from 3.63 to 2.78 at $\alpha$ value $(<0.05)$. For treatments highest average value was observed in $\mathrm{S}_{4}$ (3.40) followed by $\mathrm{S}_{5}$ (3.34) and minimum in $\mathrm{S}_{6}$ (3.03) followed by $\mathrm{S}_{2}$ (3.09). The highest percent decrease was observed in $S_{6}$ (31.2) followed by $S_{2}$ (29.7) and minimum in $\mathrm{S}_{4}(15.62)$ followed by $\mathrm{S}_{5}$ (17.35) (Table 2). Same results were obtained by [23] who showed that $\mathrm{pH}$ during storage decreases due to production of different acidic radicals. The results are also in agreements with the findings of [24] who 
showed that the decrease in $\mathrm{pH}$ is due to production of acidic components by degradation of reducing sugars and production of pectinic acid in the product.

Table2. pH value of Mandarin and Strawberry mixed fruit juice samples

\begin{tabular}{|c|c|c|c|c|c|c|c|c|c|}
\hline \multirow{2}{*}{ Treatments } & \multicolumn{7}{|c|}{ Storage intervals (Days) } & \multirow{2}{*}{ \% decease } & \multirow{2}{*}{ Average } \\
\cline { 2 - 9 } & $\mathbf{1}^{\text {st }}$ & $\mathbf{1 5}^{\text {th }}$ & $\mathbf{3 0}^{\text {th }}$ & $\mathbf{4 5}^{\text {th }}$ & $\mathbf{6 0}^{\text {th }}$ & $\mathbf{7 5}^{\text {th }}$ & $\mathbf{9 0}^{\text {th }}$ & & \\
\hline $\mathbf{S}_{\mathbf{1}}$ & 3.66 & 3.55 & 3.45 & 3.34 & 3.21 & 3.02 & 2.99 & 18.30 & $\mathbf{3 . 3 2 a}$ \\
\hline $\mathbf{S}_{\mathbf{2}}$ & 3.60 & 3.51 & 3.32 & 3.03 & 2.98 & 2.70 & 2.53 & 29.70 & $\mathbf{3 . 0 9 b c}$ \\
\hline $\mathbf{S}_{\mathbf{3}}$ & 3.62 & 3.42 & 3.12 & 3.02 & 2.88 & 2.68 & 2.49 & 29.20 & $\mathbf{3 . 1 9 b}$ \\
\hline $\mathbf{S}_{\mathbf{4}}$ & 3.60 & 3.51 & 3.32 & 3.03 & 2.98 & 2.70 & 2.53 & 15.62 & $\mathbf{3 . 4 0 a}$ \\
\hline $\mathbf{S}_{\mathbf{5}}$ & 3.63 & 3.53 & 3.52 & 3.42 & 3.21 & 3.10 & 3.00 & 17.35 & $\mathbf{3 . 3 4 a}$ \\
\hline $\mathbf{S}_{\mathbf{6}}$ & 3.62 & 3.42 & 3.12 & 3.02 & 2.88 & 2.68 & 2.49 & 31.21 & $\mathbf{3 . 0 3 c}$ \\
\hline Average & $\mathbf{3 . 6 3 a}$ & $\mathbf{3 . 5 4 a}$ & $\mathbf{3 . 3 9 b}$ & $\mathbf{3 . 2 4 c}$ & $\mathbf{3 . 1 0 d}$ & $\mathbf{2 . 9 3 e}$ & $\mathbf{2 . 7 8 f}$ & & \\
\hline
\end{tabular}

Total soluble solids (TSS) of Mandarin and Strawberry mixed fruit juice samples

The average value of total soluble solids was increased from 10.20 to $11.33^{\circ}$ brix at $\alpha$ value $(<0.05)$. The highest average value was observed in $\mathrm{S}_{6}(11.13)$ followed by $\mathrm{S}_{5}(10.95)$ and lowest average value was observed in $S_{1}$ (10.46) followed by $\mathrm{S}_{4}$ (10.53). The highest percent increase was recorded in sample $S_{6}$ (17.75) followed by $\mathrm{S}_{5}(16.10)$ and minimum in $S_{4}(6.56)$ followed by $S_{2}(6.96)$ and $S_{1}$ (7.84) (Table 3). The same slow increase in total soluble solids content was shown by [25] in their spinach orange carrot juice samples. The work of [26] on lime juice samples also showed the increase in total soluble solids.

Acidity (\%) of Mandarin and Strawberry mixed fruit juice samples

The average value of acidity was increased from 1.15 to 1.88 at $\alpha$ value $(<0.05)$. Highest average value was observed in $\mathrm{S}_{5}(1.67)$ followed by $S_{1}$ (1.63) and minimum in $\mathrm{S}_{3}$ (1.37) followed by $\mathrm{S}_{4}$ (1.38). Highest percent increase was observed in $\mathrm{S}_{6}(72.03 \%)$ followed by $\mathrm{S}_{2}(67.65 \%)$ and minimum percent increase was observed in $\mathrm{S}_{3}(55.5 \%)$ followed by $\mathrm{S}_{1}(57.14 \%)$ (Table 4). The production of carboxylic acid is responsible for increased acidity in the product. The same increasing trend in acidity was found in the work of [27]. The increasing trend in acidity was also reported by [28]. They observed an increase in acidity of pomegranate syrup samples and stated that the increase in acidity was due to oxidation of reducing sugars. Formation of pectinic acid in product is another cause of increase in acidity.

Ascorbic Acid (mg/100g) of Mandarin and Strawberry mixed fruit juice samples

The average value of ascorbic acid content of all samples was decreased from 40.30 to 28.09 at $\alpha$ value $(<0.05)$. Among treatments highest average value was observed in $\mathrm{S}_{4}$ (36.60) followed by $\mathrm{S}_{3}$ (34.87) and minimum in $\mathrm{S}_{6}(28.55)$ followed by $\mathrm{S}_{5}$ (32.94). Highest percent decrease was observed in $\mathrm{S}_{6}$ $(57.01 \%)$ followed by $\mathrm{S}_{2}(44.95 \%)$ and minimum in $\mathrm{S}_{4}(20.33 \%)$ followed by $\mathrm{S}_{3}$ $(27.95 \%)$ (Table 5). The results are in similarity with the findings of [29] while working on mango leather. The work of [30] also showed the decrease in ascorbic acid content in kinnow juice samples. The results obtained from the work of [31] also showed decrease in ascorbic acid content who stated that decrease in its content was due to the presence of oxygen in the product.

\section{Reducing Sugars of Mandarin and} Strawberry mixed fruit juice samples

The average value of reducing sugars of all samples was increased from 4.41 to 6.59 at $\alpha$ value $(<0.05)$. Among treatments highest average value was observed in $\mathrm{S}_{4}$ (5.96) 
followed by $S_{2}(5.72)$ and minimum in $S_{1}$ (5.02) followed by $S_{5}(5.26)$. Highest percent increase was observed in $\mathrm{S}_{6}(64.8 \%)$ followed by $\mathrm{S}_{5}(58.4 \%)$ and minimum in $\mathrm{S}_{1}(27.3 \%)$ followed by $\mathrm{S}_{3}(43.1 \%$ ) (Table 6). The same results were shown by [32] his work on strawberry juice and stated that inversion of sucrose is responsible for increase amount of monosaccharides in the product. The work of [33] on dehydrated mango slices also showed increase in reducing sugar amount.

Table 3. Total soluble solids content of Mandarin and Strawberry mixed fruit juice samples

\begin{tabular}{|c|c|c|c|c|c|c|c|c|c|}
\hline \multirow[t]{2}{*}{ Treatments } & \multicolumn{7}{|c|}{ Storage intervals (Days) } & \multirow{2}{*}{$\begin{array}{c}\% \\
\text { Increas } \\
\mathrm{e}\end{array}$} & \multirow[b]{2}{*}{$\begin{array}{l}\text { Averag } \\
\text { e }\end{array}$} \\
\hline & $1^{\text {st }}$ & $15^{\text {th }}$ & $30^{\text {th }}$ & $45^{\text {th }}$ & $60^{\text {th }}$ & $75^{\text {th }}$ & $90^{\text {th }}$ & & \\
\hline $\mathbf{S}_{1}$ & 10.20 & 10.32 & 10.51 & 10.72 & 1085. & 10.90 & 11.0 & 7.84 & $10.46 b$ \\
\hline $\mathbf{S}_{2}$ & 10.20 & 10.31 & 10.42 & 10.54 & 10.63 & 10.72 & 10.91 & 6.96 & $10.64 \mathrm{bc}$ \\
\hline $\mathbf{S}_{3}$ & 10.20 & 10.41 & 10.52 & 10.76 & 10.81 & 11.0 & 11.32 & 10.98 & $10.72 b$ \\
\hline $\mathbf{S}_{4}$ & 10.20 & 10.25 & 10.32 & 10.42 & 10.53 & 10.64 & 10.87 & 6.56 & $10.53 b c$ \\
\hline S5 & 10.20 & 10.42 & 10.75 & 10.93 & 11.05 & 11.47 & 11.84 & 16.10 & 10.95 a \\
\hline $\mathbf{S}_{6}$ & 10.20 & 10.57 & 10.79 & 11.02 & 11.52 & 11.82 & 12.01 & 17.75 & 11.13a \\
\hline Average & $10.23 a$ & $10.28 b$ & $10.40 b$ & $10.5 b$ & $\begin{array}{c}10.61 \\
c\end{array}$ & $\begin{array}{c}10.76 \\
\text { c }\end{array}$ & $\begin{array}{c}10.91 \\
d\end{array}$ & & \\
\hline
\end{tabular}

Table 4. Acidity content of Mandarin and Strawberry mixed fruit juice samples

\begin{tabular}{|c|c|c|c|c|c|c|c|c|c|}
\hline \multirow{2}{*}{ Treatments } & \multicolumn{7}{|c|}{ Storage intervals (Days) } & \multirow{2}{*}{$\begin{array}{c}\% \\
\text { Increase }\end{array}$} & \multirow{2}{*}{ Average } \\
\hline & $1^{\text {st }}$ & $15^{\text {th }}$ & $30^{\text {th }}$ & $45^{\text {th }}$ & $60^{\text {th }}$ & $75^{\text {th }}$ & $90^{\text {th }}$ & & \\
\hline $\mathbf{S}_{1}$ & 1.26 & 1.35 & 1.59 & 1.61 & 1.75 & 1.89 & 1.98 & 57.14 & $1.63 a b$ \\
\hline $\mathbf{S}_{2}$ & 1.02 & 1.19 & 1.29 & 1.42 & 1.53 & 1.62 & 1.71 & 67.65 & $1.39 \mathrm{c}$ \\
\hline $\mathbf{S}_{3}$ & 1.08 & 1.15 & 1.24 & 1.33 & 1.42 & 1.58 & 1.68 & 55.5 & $1.37 \mathrm{c}$ \\
\hline $\mathbf{S}_{4}$ & 1.07 & 1.20 & 1.28 & 1.38 & 1.50 & 1.53 & 1.72 & 60.74 & $1.38 \mathrm{c}$ \\
\hline $\mathbf{S}_{5}$ & 1.30 & 1.40 & 1.50 & 1.64 & 1.75 & 1.96 & 2.17 & 66.92 & $1.67 \mathbf{a}$ \\
\hline $\mathbf{S}_{6}$ & 1.18 & 1.28 & 1.33 & 1.46 & 1.76 & 1.98 & 2.03 & 72.03 & $1.57 \mathrm{~b}$ \\
\hline Average & $1.15 \mathrm{a}$ & $1.26 \mathrm{~b}$ & $1.37 \mathrm{c}$ & $1.47 d$ & $1.62 \mathrm{e}$ & $1.78 f$ & $1.88 \mathrm{~g}$ & & \\
\hline
\end{tabular}

Table 5. Ascorbic acid (mg/100g) content of Mandarin and Strawberry mixed fruit juice samples

\begin{tabular}{|c|c|c|c|c|c|c|c|c|c|}
\hline \multirow{2}{*}{ Treatments } & \multicolumn{7}{|c|}{ Storage intervals (Days) } & \multirow{2}{*}{ \%Decrease } & \multirow{2}{*}{ Average } \\
\cline { 2 - 10 } & $\mathbf{1}^{\text {st }}$ & $\mathbf{1 5}^{\text {th }}$ & $\mathbf{3 0}^{\text {th }}$ & $\mathbf{4 5}^{\text {th }}$ & $\mathbf{6 0}^{\text {th }}$ & $\mathbf{7 5}^{\text {th }}$ & $\mathbf{9 0}^{\text {th }}$ & & \\
\hline $\mathbf{S}_{\mathbf{1}}$ & 40.18 & 39.54 & 36.56 & 34.89 & 31.29 & 29.76 & 27.25 & 32.18 & $\mathbf{3 4 . 2 1 b}$ \\
\hline $\mathbf{S}_{\mathbf{2}}$ & 40.42 & 38.70 & 37.83 & 35.35 & 31.20 & 27.28 & 22.25 & 44.95 & $\mathbf{3 3 . 2 9} \mathbf{b}$ \\
\hline $\mathbf{S}_{\mathbf{3}}$ & 40.25 & 39.15 & 37.03 & 35.21 & 33.18 & 30.26 & 29.00 & 27.95 & $\mathbf{3 4 . 8 7 a b}$ \\
\hline $\mathbf{S}_{\mathbf{4}}$ & 40.18 & 39.01 & 38.92 & 36.89 & 35.84 & 33.34 & 32.01 & 20.33 & $\mathbf{3 6 . 6 0} \mathbf{a}$ \\
\hline $\mathbf{S}_{\mathbf{5}}$ & 40.58 & 38.48 & 36.30 & 33.12 & 30.67 & 27.21 & 24.25 & 40.24 & $\mathbf{3 2 . 9 4 c d}$ \\
\hline $\mathbf{S}_{\mathbf{6}}$ & 40.20 & 35.20 & 31.12 & 29.67 & 25.61 & 20.72 & 17.28 & 57.01 & $\mathbf{2 8 . 5 5 c}$ \\
\hline Average & $\mathbf{4 0 . 3 0 a}$ & $\mathbf{3 8 . 6 8 a b}$ & $\mathbf{3 6 . 9 6 b}$ & $\mathbf{3 4 . 5 2 c}$ & $\mathbf{3 1 . 8 3 d}$ & $\mathbf{2 8 . 9 3 e}$ & $\mathbf{2 6 . 0 1 f}$ & & \\
\hline
\end{tabular}


Rani et al.

Table 6. Reducing Sugar content of Mandarin and Strawberry mixed fruit juice samples

\begin{tabular}{|c|c|c|c|c|c|c|c|c|c|}
\hline \multirow{2}{*}{ Treatments } & \multicolumn{7}{|c|}{ Storage intervals (Days) } & \multirow{2}{*}{$\begin{array}{c}\% \\
\text { Increase }\end{array}$} & \multirow{2}{*}{ Average } \\
\hline & $\mathbf{1}^{\text {st }}$ & $15^{\text {th }}$ & $30^{\text {th }}$ & $45^{\text {th }}$ & $60^{\text {th }}$ & $75^{\text {th }}$ & $90^{\text {th }}$ & & \\
\hline $\mathbf{S}_{1}$ & 4.50 & 4.65 & 4.76 & 4.86 & 5.17 & 5.49 & 5.73 & 27.3 & 5.02d \\
\hline $\mathbf{S}_{2}$ & 4.50 & 4.85 & 5.10 & 5.56 & 6.33 & 6.78 & 6.95 & 54.4 & 5.72ab \\
\hline $\mathbf{S}_{3}$ & 4.33 & 4.51 & 5.73 & 5.91 & 6.02 & 6.18 & 6.20 & 43.1 & $5.55 \mathrm{bc}$ \\
\hline $\mathbf{S}_{4}$ & 4.80 & 5.00 & 5.21 & 5.88 & 6.66 & 6.95 & 7.21 & 49.2 & $5.96 a$ \\
\hline $\mathbf{S}_{5}$ & 4.09 & 4.85 & 5.00 & 5.15 & 5.32 & 5.90 & 6.48 & 58.4 & $5.26 \mathrm{~cd}$ \\
\hline $\mathrm{S}_{6}$ & 4.21 & 4.74 & 5.05 & 5.26 & 5.50 & 6.81 & 6.94 & 64.8 & $5.50 \mathrm{bc}$ \\
\hline Average & 4.41d & $4.77 \mathrm{~cd}$ & $5.14 \mathrm{~cd}$ & $5.44 \mathrm{bcd}$ & 5.83abc & 6.35ab & $6.59 \mathrm{a}$ & & \\
\hline
\end{tabular}

Non-Reducing Sugars of Mandarin and Strawberry mixed fruit juice samples

The value of non-reducing sugar of all samples was decreased from 3.34 to 1.53 at $\alpha$ value $(<0.05)$. Among treatments highest average value was observed in $\mathrm{S}_{1}$ (2.68) followed by $\mathrm{S}_{4}(2.64)$ and minimum in $\mathrm{S}_{6}$ (1.64) followed by $\mathrm{S}_{2}$ (2.16). Highest percent decrease was observed in $\mathrm{S}_{6}(79.39 \%)$ followed by $\mathrm{S}_{2}(64.81 \%)$ and minimum in $\mathrm{S}_{5}$ (30.33) followed by $\mathrm{S}_{1}(40 \%)$ (Table 7$)$. The same decreasing trend in non-reducing sugar content was shown by [34] in melon cube samples treated with non-caloric sweeteners and stated that non reducing sugar convert to reducing sugar that cause decrease in their content. The results obtained from the work of [35] are also supporting the results obtained from our work.

Color score of Mandarin and Strawberry mixed fruit juice samples

The average color score for all samples was decreased from 8.38 to 3.71 at $\alpha$ value $(<0.05)$. Among treatments highest average score was obtained by $\mathrm{S}_{4}$ (7.20) followed by $\mathrm{S}_{3}(6.23)$ and minimum by $\mathrm{S}_{6}(2.69)$ followed by $S_{2}(5.29)$ (Table 8 ). The same results were shown by [36] on their work on Indian gooseberry juice. The work of [37] showed the decrease in color score of fruit leather. The results obtained in the work of [38] are also in agreement with the results obtained in our work.

Table 7. Non reducing sugar content of Mandarin and Strawberry mixed fruit juice samples

\begin{tabular}{|c|c|c|c|c|c|c|c|c|c|}
\hline \multirow{2}{*}{ Treatments } & \multicolumn{7}{|c|}{ Storage intervals (Days) } \\
\cline { 2 - 10 } & $\mathbf{1}^{\text {st }}$ & $\mathbf{1 5}^{\text {th }}$ & $\mathbf{3 0}^{\text {th }}$ & $\mathbf{4 5}^{\text {th }}$ & $\mathbf{6 0}^{\text {th }}$ & $\mathbf{7 5}^{\text {th }}$ & $\mathbf{9 0}^{\text {th }}$ & $\begin{array}{c}\text { \%Decre } \\
\text { Average } \\
\text { ase }\end{array}$ & \\
\hline $\mathbf{S}_{\mathbf{1}}$ & 3.30 & 3.28 & 3.16 & 2.46 & 2.46 & 2.14 & 1.98 & 40 & $\mathbf{2 . 6 8 a}$ \\
\hline $\mathbf{S}_{\mathbf{2}}$ & 3.38 & 3.21 & 2.53 & 1.86 & 1.73 & 1.25 & 1.19 & 64.81 & $\mathbf{2 . 1 6 c d}$ \\
\hline $\mathbf{S}_{\mathbf{3}}$ & 3.36 & 3.26 & 3.06 & 2.70 & 1.19 & 1.44 & 1.31 & 61.38 & $\mathbf{2 . 3 3 b c}$ \\
\hline $\mathbf{S}_{\mathbf{4}}$ & 3.37 & 3.27 & 3.00 & 2.79 & 2.59 & 1.81 & 1.67 & 50.45 & $\mathbf{2 . 6 4 a b}$ \\
\hline $\mathbf{S}_{\mathbf{5}}$ & 3.33 & 3.11 & 3.09 & 2.86 & 2.61 & 2.51 & 2.32 & 30.33 & $\mathbf{2 . 8 3 a}$ \\
\hline $\mathbf{S}_{\mathbf{6}}$ & 3.30 & 2.85 & 2.51 & 1.62 & 1.43 & 1.20 & 0.68 & 79.39 & $\mathbf{1 . 9 4 d}$ \\
\hline Average & $\mathbf{3 . 3 4 a}$ & $\begin{array}{c}\mathbf{3 . 1 6} \\
\mathbf{a b}\end{array}$ & $\begin{array}{c}\mathbf{2 . 8 9} \\
\mathbf{b}\end{array}$ & $\mathbf{2 . 3 8 c}$ & $\begin{array}{c}\mathbf{2 . 0 0} \\
\mathbf{d}\end{array}$ & $\begin{array}{c}\mathbf{1 . 7 3} \\
\mathbf{d e}\end{array}$ & $\begin{array}{c}\mathbf{1 . 5 3} \\
\mathbf{e}\end{array}$ & & \\
\hline
\end{tabular}


Table 8. Color score of mandarin and strawberry mixed fruit juice samples

\begin{tabular}{|c|c|c|c|c|c|c|c|c|}
\hline \multirow{2}{*}{ Treatments } & \multicolumn{7}{|c|}{ Storage intervals (Days) } & \multirow{2}{*}{} \\
\cline { 2 - 9 } & $\mathbf{1}^{\text {st }}$ & $\mathbf{1 5}^{\text {th }}$ & $\mathbf{3 0}^{\text {th }}$ & $\mathbf{4 5}^{\text {th }}$ & $\mathbf{6 0}^{\text {th }}$ & $\mathbf{7 5}^{\text {th }}$ & $\mathbf{9 0}^{\text {th }}$ & Average \\
\hline $\mathbf{S}_{\mathbf{1}}$ & 7.78 & 6.60 & 6.28 & 6.23 & 5.46 & 4.00 & 3.17 & $\mathbf{5 . 6 5 b c}$ \\
\hline $\mathbf{S}_{\mathbf{2}}$ & 8.86 & 6.67 & 5.56 & 5.00 & 4.38 & 3.58 & 2.98 & $\mathbf{5 . 2 9 c}$ \\
\hline $\mathbf{S}_{\mathbf{3}}$ & 8.51 & 6.89 & 6.53 & 6.00 & 5.53 & 5.13 & 5.00 & $\mathbf{6 . 2 3 b}$ \\
\hline $\mathbf{S}_{\mathbf{4}}$ & 8.76 & 7.78 & 7.32 & 7.00 & 6.98 & 6.53 & 6.00 & $\mathbf{7 . 2 0 a}$ \\
\hline $\mathbf{S}_{\mathbf{5}}$ & 8.81 & 6.89 & 6.22 & 5.89 & 5.78 & 5.00 & 4.12 & $\mathbf{6 . 1 0 b}$ \\
\hline $\mathbf{S}_{\mathbf{6}}$ & 7.58 & 4.78 & 3.26 & 1.20 & 1.00 & 1.00 & 1.00 & $\mathbf{2 . 6 9 d}$ \\
\hline Average & $\mathbf{8 . 3 8 a}$ & $\mathbf{6 . 4 4 b}$ & $\mathbf{5 . 8 6 b c}$ & $\mathbf{5 . 2 2 c d}$ & $\mathbf{4 . 8 9 d e}$ & $\mathbf{4 . 2 1 e f}$ & $\mathbf{3 . 7 1 f}$ & \\
\hline
\end{tabular}

Flavor score of Mandarin and Strawberry mixed fruit samples

The judges score for flavor of all samples was decreased from 8.63 to 3.70 at $\alpha$ value $(<0.05)$. Among treatments highest average score was received by $\mathrm{S}_{4}(7.83)$ followed by $\mathrm{S}_{3}(6.95)$ and minimum by $\mathrm{S}_{6}(2.95)$ followed by $\mathrm{S}_{5}(4.86)$ (Table 9). The same decrease in flavor score was observed by [39] on orange juice. The work of [40] are also supporting our results who observed loss in flavoring compounds during storage.

Taste score of Mandarin and Strawberry mixed fruit juice samples

The judges score for taste of all samples was decreased from 8.52 to 3.91 at $\alpha$ value $(<0.05)$. Among treatments highest average score was achieved by $\mathrm{S}_{4}$ (7.51) followed by $\mathrm{S}_{3}(7.00)$ and minimum by $\mathrm{S}_{6}(2.97)$ followed by $S_{2}(5.01)$ (Table 10). The same declining trend in the score of judges for taste was shown by $[41,42]$ who observed the production of different chemical compounds that gives bitter taste to product and cause the decline in their acceptability rates.

Overall Acceptability score of Mandarin and Strawberry mixed fruit juice samples The overall acceptability score of all samples was decreased from 8.58 to 4.13 at $\alpha$ value $(<0.05)$. Among treatments highest average score was obtained by $\mathrm{S}_{4}$ (8.01) followed by $\mathrm{S}_{3}(7.41)$ and minimum by $\mathrm{S}_{6}(4.72)$ followed by $\mathrm{S}_{5}$ (5.69) (Table 11). The same declining trend was shown by [43] in their work on apricot fruit bar. The results of [44] are also supporting our results. They found the decline in the sensory properties of orange juice stored in glass bottles.

Table 9. Flavor score of Mandarin and Strawberry mixed fruit juice samples

\begin{tabular}{|c|c|c|c|c|c|c|c|c|}
\hline \multirow{2}{*}{ Treatments } & \multicolumn{7}{|c|}{ Storage interval (Days) } & \multirow{2}{*}{ Average } \\
\cline { 2 - 8 } & $\mathbf{1}^{\text {st }}$ & $\mathbf{1 5}^{\text {th }}$ & $\mathbf{3 0}^{\text {th }}$ & $\mathbf{4 5}^{\text {th }}$ & $\mathbf{6 0}^{\text {th }}$ & $\mathbf{7 5}^{\text {th }}$ & $\mathbf{9 0}^{\text {th }}$ & \\
\hline $\mathbf{S}_{\mathbf{1}}$ & 8.56 & 7.23 & 6.58 & 5.67 & 4.08 & 3.98 & 2.87 & $5.59 \mathrm{~cd}$ \\
\hline $\mathbf{S}_{\mathbf{2}}$ & 8.44 & 6.89 & 6.11 & 5.87 & 5.67 & 4.87 & 4.43 & $\mathbf{6 . 0 4 c}$ \\
\hline $\mathbf{S}_{\mathbf{3}}$ & 8.89 & 7.89 & 7.67 & 7.00 & 6.00 & 5.78 & 5.29 & $\mathbf{6 . 9 3 b}$ \\
\hline $\mathbf{S}_{\mathbf{4}}$ & 9.0 & 8.72 & 8.13 & 8.00 & 7.49 & 7.00 & 6.49 & $\mathbf{7 . 8 3 a}$ \\
\hline $\mathbf{S}_{\mathbf{5}}$ & 7.33 & 6.00 & 5.20 & 5.00 & 4.14 & 3.44 & 2.00 & $\mathbf{4 . 8 6 d}$ \\
\hline $\mathbf{S}_{\mathbf{6}}$ & 8.67 & 4.34 & 2.67 & 2.00 & 1.00 & 1.00 & 1.00 & $\mathbf{2 . 9 5 e}$ \\
\hline Average & $\mathbf{8 . 6 3 a}$ & $\mathbf{6 . 8 4 b}$ & $\mathbf{6 . 0 6} \mathbf{b c}$ & $\mathbf{5 . 5 9} \mathbf{c d}$ & $\mathbf{4 . 7 3 d e}$ & $\mathbf{4 . 3 5 e f}$ & $\mathbf{3 . 7 0 f}$ & \\
\hline
\end{tabular}


Table 10. Taste score of Mandarin and Strawberry mixed fruit juice samples

\begin{tabular}{|c|c|c|c|c|c|c|c|c|}
\hline \multirow{2}{*}{ Treatments } & \multicolumn{7}{|c|}{ Storage intervals (Days) } & \multirow{2}{*}{ Average } \\
\cline { 2 - 8 } & $\mathbf{1}^{\text {st }}$ & $\mathbf{1 5}^{\text {th }}$ & $\mathbf{3 0}^{\text {th }}$ & $\mathbf{4 5}^{\text {th }}$ & $\mathbf{6 0}^{\text {th }}$ & $\mathbf{7 5}^{\text {th }}$ & $\mathbf{9 0}^{\text {th }}$ & \\
\hline $\mathbf{S}_{\mathbf{1}}$ & 8.44 & 7.33 & 6.32 & 6.00 & 5.87 & 5.00 & 4.01 & $\mathbf{6 . 1 4 b}$ \\
\hline $\mathbf{S}_{\mathbf{2}}$ & 8.32 & 6.67 & 6.45 & 4.31 & 3.54 & 3.00 & 2.81 & $\mathbf{5 . 0 1 c}$ \\
\hline $\mathbf{S}_{\mathbf{3}}$ & 8.80 & 8.00 & 7.58 & 7.00 & 6.56 & 6.23 & 5.85 & $\mathbf{7 . 0 0 a}$ \\
\hline $\mathbf{S}_{\mathbf{4}}$ & 8.85 & 8.33 & 8.00 & 7.84 & 7.10 & 6.45 & 6.00 & $\mathbf{7 . 5 1 a}$ \\
\hline $\mathbf{S}_{\mathbf{5}}$ & 8.42 & 6.67 & 5.46 & 5.00 & 4.46 & 4.00 & 3.76 & $\mathbf{5 . 3 9 b c}$ \\
\hline $\mathbf{S}_{\mathbf{6}}$ & 8.28 & 4.53 & 2.00 & 1.00 & 1.00 & 1.00 & 1.00 & $\mathbf{2 . 9 7 d}$ \\
\hline Average & $\mathbf{8 . 5 2 a}$ & $\mathbf{6 . 9 2 b}$ & $\mathbf{6 . 1 4 b c}$ & $\mathbf{5 . 3 6 c d}$ & $\mathbf{4 . 5 9 d e}$ & $\mathbf{4 . 2 8 e}$ & $\mathbf{3 . 9 1 e f} \mathbf{m}$ & \\
\hline
\end{tabular}

Table 11. Overall acceptability score of Mandarin and Strawberry mixed fruit juice samples

\begin{tabular}{|c|c|c|c|c|c|c|c|c|}
\hline \multirow{2}{*}{ Treatments } & \multicolumn{7}{|c|}{ Storage intervals (Days) } & \multirow{2}{*}{ Average } \\
\cline { 2 - 8 } & $\mathbf{1}^{\text {st }}$ & $\mathbf{1 5}^{\text {th }}$ & $\mathbf{3 0}^{\text {th }}$ & $\mathbf{4 5}^{\text {th }}$ & $\mathbf{6 0}^{\text {th }}$ & $\mathbf{7 5}^{\text {th }}$ & $\mathbf{9 0}^{\text {th }}$ & \\
\hline $\mathbf{S}_{\mathbf{1}}$ & 8.89 & 7.89 & 6.00 & 5.28 & 5.00 & 4.88 & 3.98 & $\mathbf{5 . 7 6 b}$ \\
\hline $\mathbf{S}_{\mathbf{2}}$ & 8.00 & 6.43 & 5.44 & 4.15 & 3.01 & 2.47 & 2.00 & $\mathbf{6 . 0 8 b}$ \\
\hline $\mathbf{S}_{\mathbf{3}}$ & 8.54 & 7.33 & 7.11 & 6.33 & 6.00 & 5.87 & 5.00 & $\mathbf{7 . 4 1 a}$ \\
\hline $\mathbf{S}_{\mathbf{4}}$ & 8.61 & 7.14 & 7.00 & 6.20 & 5.89 & 5.00 & 4.89 & $\mathbf{8 . 0 1 a}$ \\
\hline $\mathbf{S}_{\boldsymbol{5}}$ & 8.67 & 6.67 & 5.44 & 5.00 & 4.89 & 4.00 & 3.89 & $\mathbf{5 . 6 9 b}$ \\
\hline $\mathbf{S}_{\mathbf{6}}$ & 8.78 & 4.00 & 3.00 & 2.00 & 1.00 & 1.00 & 1.00 & $\mathbf{4 . 7 2 c}$ \\
\hline Average & $\mathbf{8 . 5 8 a}$ & $\mathbf{7 . 0 7 b}$ & $\mathbf{6 . 1 7 b c}$ & $\mathbf{5 . 5 5 c d}$ & $\mathbf{5 . 0 0 c d e}$ & $\mathbf{4 . 4 8 d e}$ & $\mathbf{4 . 1 3 e}$ & \\
\hline
\end{tabular}

\section{Conclusion and recommendations}

From this study it was concluded that the mixing of fruit juice and addition of preservatives strongly affect the products shelf life and consumer acceptability. During this study we found $\mathrm{S}_{4}[(1: 1)+0.075 \%$ Sodium Benzoate Sodium Benzoate +0.025 Potassium Sorbate] more acceptable while $\mathrm{S}_{6}$ [controlled] showed unsatisfactory results both physiochemically and organoleptically during storage. Further study is recommended on refrigeration and mixing of more than two fruits is recommended to make the product more nutritious. Nutritional assessment and packaging effect study is also recommended for future work.

\section{Authors' contributions}

Conceived and designed the experiments: A Zeb \& S Rani, Performed the experiments: S Rani, Analyzed the data: U Shahni, Contributed materials/ analysis/ tools: S Rani, U shahni \& M Ayub, Wrote the paper: S Rani.

\section{References}

1. Hussain IA, Zeb A, Shakir I \&Shah AS (2008). Combined effect of potassium sorbate and sodium benzoate on individual and blended juices of apricot and apple fruits grown in Azad Jammu and Kashmir. Pak j Nut 7(10):181-185.

2. Bondari K (2000). Mixture experiments and their applications in agricultural research coastal plain station, University of Georgia 31793-0748.

3. Piepel GF \& Cornell (1994). Mixture experiment approaches: examples, discussion and recommendations. $J$ Quality Tech 26:177-196.

4. Dake BC, Sethi V, Prasad R \&Batra PK (2001). Use of experiments with mixture methodology for quality evaluation of mixed fruit juice/ pulp RTS baverage. $J$ Food Sci Tech 38:615-618.

5. Montgomery DC \& Voth SR (1994). Multicollinearity and leverage in mixture experiments. J Quality Tech 26:96-108. 
6. Chauhan OP, Archana BS, Singh A, Raju PS \&Bawa AS(2012). A refreshing baverage from mature coconut water blended with lemon juice. J Food Sci Techl 1-7.

7. Rathod AS, Shakya B \& Ade KD (2014).Studies on effect of thermal processing on preparation of bael fruit RTS blended with Aonla. Int J Res EngAdv Tech 2(3): $1-5$

8. Falade OS, Sowunmi, Oladipo A, Tobosun $\&$ Adewusi SRA (2003). The level of organic acids in some Nigerian fruit and their effect on mineral availability in composite diet. Pak JNutr 2(2): 82-83.

9. Ahmad M C\& Khan MA (1986). Technological studies on citrus and other fruit based drinks. Nucleus 23(34): 41-45.

10. Agric Stat of Pakistan (2007-08). Fruits, vegetables and condiments statistics of Pakistan. Govt of Pakistan. Ministry of Food and Livestock (Economic Wing) Islamabad Pakistan 1-89.

11. Childer NF (1983). Strawberry growing. Modern Fruit Science Gainesvile. Hort Publ 451-480.

12. Ford A, Hansen $K$, Harrington $M$, Moisander J, Nottingham S, Prytz S \& Zorin M (1997). Subjective and objective determination of strawberry quality. Acta Horticulture 439(1):319-223.

13. May G, Pritts M \& Kelly M (1994). Seasonal patterns of growth and tissue nutrient content in strawberries. J Plant Nut 17 (4): 1149-1162.

14. Ayub M, Ullah J, Muhammad A \& Zeb A (2010). Evaluation of strawberry juice preserved with chemical preservation at refrigeration temperature. Int $J$ Nut Metab 2(2):27-32.

15. U S Deptt of agric (1998). Nutrients database for standard references. $w w w$ Oregon-Strawberries org.

16. Mehmood Z, Zeb A, Ayub M Bibi Nbadsha A \& Ullah I (2008). Effect of pasteurization and chemical preservatives on the quality and shelf stability of apple juice. Amer J Food Tech 20:147-153.

17. Alzamora SM, Tapia MS, Lopez MA (2000). Minimally processed fruits and vegetables: Fundamental aspects and application. Gaithersburg MD:Aspen Publishers Inc 1-62p.

18. Tetra Pak (2004). The orange book. Tetra pack processing system Lund (Sweden).

19. AOAC (2012).Official Methods of Analysis.The Association of the official Analytical Chemists.Arlington17th Ed Chap 17.

20. Larmond E (1977). Laboratory method of sensory evaluation of food. Publication of deptt: Agric. Ottawa Canada 177-183p.

21. Steel RGD \& Torrie JH (1980). Principals and procedure of statistics. A biometrical approach. McGraw Hill New York. 2nd Ed 633p.

22. Chochron WC \& Cox GM (1965). Experimental design. Jhon Wiley and Sons Inc New York 1-50p.

23. AyubM, Ullah J, Zeb A \& Muhammad A (2009). Evaluation of strawberry juice preserved with chemical preservatives at refrigeration temperature. Int $J$ Nut Metabolism 2(2): 027-032.

24. Phimpherian C, Angchud A, Jangshud K,Therdthai N, Prinyawiwatkul WHK (2011). Physicochemical characteristics and sensory optamization of pineapple leather snack as affected by glucose syrup and pectin concentrations. Int J of Food Sci Tech 46:972-981.

25. Rodriqo D, Arranz JI, Koch S, Frigola, Rodriqo MC, Esteve MJ, Calvo C \&Radriqo M (2003). Physiochemical characteristics and quality of refrigerated spinach orange carrot juices and influence of storage conditions. $J$ Food Sci 68(6):2111-2116.

26. Sarolia DK \&Mukarjee S (2002). Comparative efficiency of different preservation methods in keeping quality of lime (Citrus aurantifolia) single juice during storage. Haryana J Hort Sci 31(34):185-188.

27. Zeb A, Ahmed I \&Ayub M (2009). Grape juice preservation with benzoate and sorbate. J Adv food Sci 31(1):17-21.

28. Ayub M \& Bilal KM (2001). Effect of different light conditions and colored glass 
bottles on the relation of quality characteristics of pomegranate syrup during storage at room temperature. Sarhad j agric 17(4):629-632.

29. Azerdo HMC, Brito ES, Moreira GEG, Farias VL, Bruno LM (2000). Effect of drying and storage time on the physiochemical prpoerties of mango leather. Int J of Food Sci Tech 41:635-638.

30. Sandhu KS \& Singh S (2001). Studies on the factors affecting the physico-chemical and organoleptic properties of kinnow juice. J Food Sci \& Tech 38(3):266-269.

31. Wisal S, Ullah J, Zeb A, Khan MZ (2008).Effect of refrigeration temperature, sugar concentrations and different chemical preservatives on the storage stability of strawberry juice. Int $J$ Engg Tech 3:160-168.

32. Wisal S, Zeb A, Ayub M \& Ullah I (2013). Refrigeration storage studies of strawberry juice with tss of 7.5 and 20.5 brix treated with sodium benzoate and potassium sorbate.Sarhad J Agric 29:3.

33.Kumar SP, Sagarand VR (2008).Quality of osmovac dehydrated ripe mango slices influenced by packaging material and storage temperature. $J$ Sci Industries Research 67:1108-1114.

34. Zia A, Ayub M (2012). Quality Evaluation of melon cubes preserved in sweetener solution. MSc thesis. Food Sci Tech Depttuniof AgricPeshawar.

35. Ghoria K \&Khurdiya DS (1998). Storage of heat processed Kinnow (Mandarin) Juice. $J$ of Food Sci\& Tech 35(5):422-424.

36. Jain SK \& Khurdiya DS (2004). Vit C enrichmentt of fruit juice based ready to serve beverages through blending of
Indian gooseberry (Emblica officinalis gaertn) juice. Plant Foods for Human Nutrition 59:63-66.

37. Naz R (2012). Physical properties, sensory attributes and consumer preferances of fruit leather. Pak J Food Sci 22:188-190.

38. Jain PK \&Nema PK (2007). Processing pulp of various cultivars of guava (psidiumguajava L) for leather production. Int pub AgriEnggInt 9:1-9.

39. Jain S, Shankla APK,Dashora A \&Shankla AK (2003). Physiochemical and sensory properties of orange drink. J Food Sci Tech India 40(6):656-659.

40. Bezman Y, Russell L, Rouseff\&Naim M (2001).2-Methyl-3-furanthiol \&methional are possible off-flavours in nstored orange juice. J Agric Food Chem 49(5): 425-432.

41. Okilya S, Muskiya IM \&Kaaya AN (2009). Effect of solar drying on the quality and acceptability of jack fruit leather. Electron J Envr Agri Food chem 9:101-111.

42. Nelugen SE \& Mahendran T (2010). Preparation of ready to serve (RTS) baverages from palmyrah (Borassus flabelifer L.) fruit pulp. J Agric Sci 5(2):234-237.

43. Sharma SK, Chaudary SP, Rao VK, Yadav VK \& Bisht TS (2013). Standardization of technology for preparation and storage of wild apricot fruit bar. J Food Sci Tech 50:784-790.

44. Khan SH, Khan A, Litaf U, Shah AS, Khan MA, Ali MS, Shah FN, Maqbool Z, Adnan M \& Rani S (2015). Effect of different concentrations of guava pulp, apple pulp and sugar solution on the shelf stability of blend leather storage at ambient temperature. J Food Process Technol6:7. 